\title{
THE STEEL AND SHIPBUILDING INDUSTRIES OF SOUTH KOREA: RISING EAST ASIA AND GLOBALIZATION
}

\author{
Kyoung-ho Shin \\ Department of Psychology, Sociology, and Counseling \\ Northwest Missouri State University \\ kshin@nwmissouri.edu \\ Paul S. Ciccantell \\ Department of Sociology \\ Western Michigan University \\ paul.ciccantell@wmich.edu
}

\begin{abstract}
In this paper, we focus on the roles of the steel and shipbuilding industries as generative sectors in Korea's rapid economic ascent. We argue that a worldsystems analysis focusing on these generative sectors provides a more complete understanding of Korea's rapid economic ascent than do other theoretical models. We outline the similarities between this case and those analyzed by Bunker and Ciccantell $(2005,2007)$ both in terms of the central role of generative sectors in raw materials and transport industries and how the creation and growth of these two industrial sectors shaped institutional patterns and the broader economic ascent of South Korea and East Asia. Even though South Korea has not and may never become a challenger for global hegemony, its rapid ascent has helped reshape East Asia and the capitalist world-economy. We use the model of generative sectors to analyze the critical industries that underlay and shaped South Korea's ascent from a low wage, light industry base to a world leader in electronics, automobiles, and other advanced industries.
\end{abstract}

\section{INTRODUCTION}

How did South Korea move from being one of the world's poorest nations embroiled in one of the Cold War's bloodiest conflicts to a rapidly rising semiperipheral nation challenging for core status today with world-leading research, development and production in shipbuilding, electronics, and other industries? ${ }^{1}$ In this paper, we use world-systems analysis not to focus on the maturity or

${ }^{1}$ This study understands South Korea as an upwardly mobile semiperiphery (Martin 1990; Henderson and Appelbaum 1992; Bunker and Ciccantell 2007). We use the conceptual tool of 'generative sectors' to discuss not the structural features of semiperiphery and core, but instead the processes of the Korean economy's ascendance to trade dominance in some sectors. For the 
decline of hegemonic power or on a poor periphery, but instead to provide a more comprehensive analysis of Korean economic ascent. Numerous elements of Korea's dramatic economic growth have been examined, including the importance of "flying geese" following Japan's example, the role of Cold War geopolitical support for Korean development, the role of authoritarian developmentalism, the impacts of crony capitalism, and the role of state-driven export-led industrialization (for key analyses of Korea's rapid ascent, see Amsden (1989), Appelbaum and Henderson (1992), Bradshaw, Kim and London (1993), Cumings (1984), Deyo (1987), Kohli (2004), Wade (1990a), and Woo (1991). We argue that a world-systems analysis focusing on the key generative sectors provides a more complete understanding of Korea's rapid economic ascent.

Neoliberal economists' interpretation of the rapid rise of South Korea and the other Asian Tigers as the result of market friendly policies, best exemplified in the World Bank's (1993) report, was debunked both by the events of the Asian financial crisis and by a host of analysts from a variety of perspectives (e.g. Burkett and Hart-Landsberg 2000; Amsden 1989, 1994; Wade 1990b, 1996; Kohli 2004; Ozawa 2001). Alternative explanations offered by these and other analysts of the rapid rise of South Korea focused on institutional patterns of the South Korean state and the chaebol (large industrial groups) (Amsden 1989; Woo 1991; Kohli 2004), the broader rise of Asia (Arrighi 1996; Arrighi, Hamashita and Selden 2003; Frank 1998; Peng 2002), and participation in the flying geese model of development led by Japan (Ozawa 2001, 2003, 2005; Hayter and Edgington 2004; Kojima 2000; Korhonen 1994; Romm 1992; Cutler and Ozawa 2007). Each of these lines of analysis captures a critical element of South Korea's rapid economic ascent. These institutional patterns are obviously critical to South Korea's economic ascent, as are the relationship with Japanese firms and the Japanese state that are emphasized particularly in the flying geese model but also in the rise of Asia model. We will show in this paper the similarities between this case of rapid economic ascent and those analyzed by Bunker and Ciccantell $(2005,2007)$ both in terms of the central role of generative sectors in raw materials and transport industries and how the creation and growth of these two industrial sectors shaped institutional patterns and the broader economic ascent of South Korea and East Asia. Generative sectors serve as crucibles for institutional patterns in economies that are able to sustain economic ascent for long periods (Bunker and Ciccantell 2005, 2007). Even though South Korea has not and may never become a challenger for global hegemony, its rapid ascent has helped reshape East Asia and the capitalist world-economy of the late twentieth and early twenty-first centuries. We use the model of generative sectors within the evolving capitalist world-economy to analyze the critical industrial sectors that underlay and shaped South Korea's ascent, steel and shipbuilding, from a low wage, light industry base to a world leader in electronics, automobiles, and other advanced industries. The institutional patterns, relationships with Japan, and Korea's place in the broader rise of Asia were themselves critically shaped by the development of these two industrial sectors, as we will show below.

The South Korean economy has grown remarkably since World War II, becoming a major player in the global economy by the 1990s. In 2003, the value of South Korean exports and imports totaled US\$198.3 billion (2.6\% of the world) and US $\$ 178.8$ billion (2.3\%) respectively. In the same year, South Korea produced 3.2 million automobiles, $5.2 \%$ of total global production and ranking 6 th in the world. Electronics production totaled US $\$ 69.8$ billion, trailing only the U.S.

discussion of how East Asian capitalism has gone far toward freeing itself from dependence on the economic and political power of the U.S., see Arrighi (1996). 
and Japan. Steel production was 46.3 million tons in $2003,4.8 \%$ of world production (5th in the world) and the shipbuilding industry built 7,265,000 CG/T of ships, 32.4\% of world production (ranked 1st in the world) (National Statistics Office 2004). South Korean ascent in the global economy prompted a number of analyses of the role of the Korean state and its policies of exportoriented industrialization, labor control, and state-business relationships (Amsden 1989; Deyo 1987; Kim 1997; Kohli 2004). The South Korean government has been flexible in shifting development policies from light industry (e.g., manufacturing of apparel and shoes) to heavy and high value-added industries such as automobiles and electronics, demonstrating its high capacity to adopt timely strategies and mobilize new technologies in response to the dynamically changing global market (Amsden 1989; D’Costa 1994).

Although rapid economic growth depends on secure raw materials supplies and on efficient transport systems, only limited scholarly attention has been explicitly paid to the generative sectors of raw materials and transportation, the steel and shipbuilding industries, in Korean economic development. Several analyses of Korea's ascent pay attention to some elements of these critical sectors, for example, Amsden's (1989) pioneering analysis includes discussions of several key issues in the development of the steel industry, and other studies of state policy such as Kohli (2004), Wade (1990) and Woo (1991) use examples from these sectors. However, none of these analyses presents a coherent theoretical understanding of why these sectors are so critical for state policies, firm strategies, and Korea's overall development process. These sectors are precisely the same ones that drove the critical cases of transformative economic ascent over the past five centuries: Portuguese capability to open new maritime routes for the supply of sugar, tobacco, and turtle oil in the fifteenth century; Holland's dominance of timber access for shipbuilding; British preeminence in shipbuilding and shipping to transport a variety of resources such as tin, coal, timber, rubber, and cotton; America's westward expansion with advanced transportation technologies and the steel industry; and Japanese trade dominance of coal and iron ore at a bigger scale and over longer distances (Bunker and Ciccantell 2005). Japan became the key model for and often a partner in South Korean development efforts (Bunker and Ciccantell 2007). These sectors have been shown elsewhere (Bunker and Ciccantell 2005, 2007) to be critical elements of long term sustained ascent in the capitalist world-economy. In this paper, we utilize this theoretical and empirical understanding to examine the case of South Korea. Our analysis of South Korea's rapid ascent is different in some key aspects from these earlier cases, particularly because Korea has risen from extreme poverty and colonial status to the semiperiphery and is challenging for core status. In other respects, the South Korean case strongly resembles these earlier cases, including the central role of the existing hegemon in supporting the rising economy's ascent and the central roles of steel and shipbuilding during this ascent. These similarities and differences, and the parallels between the rise of South Korea and of China, make this case study of South Korea an important step in a more general analysis of ongoing changes in the capitalist world-economy resulting from the rise of East Asia and an opportunity to assess the utility of this theoretical model for examining other cases of rapid economic ascent that do not challenge for hegemonic status.

These generative sectors have contributed greatly to Korean economic growth as part of export-oriented industrial policies (for the different strategies of export-oriented industrialization for resource poor nations such as Japan and South Korea and import substitution industrialization for resource rich economies like nations in Latin America, see Gereffi 1992:90-93). The share of basic metals and metal products and machinery in Korean exports grew steadily, from $13 \%$ in 
1960 to $26.9 \%$ in 1980 and to $49.5 \%$ in 2000 (see Table 7.3 in Song 2003:134). A rapidly growing economy must create the physical and spatial conditions for obtaining secure and low cost supplies of various raw materials: "the beginning of economic ascent requires successful coordination of domestic technological advances, particularly in heavy industry and transport, with the external solution of access to cheap and steady sources of the raw materials used for heavy industry" (Ciccantell and Bunker 2004:468).

Why are raw materials still important even in the current era of high technology, information, and knowledge-intensive products, and characterized as dematerializing by some? In fact, "old economy" heavy industry is "simply relocating to lower cost producing nations in the semiperiphery and periphery such as South Korea, Brazil, and China. The world economy uses more material every year; it is simply produced increasingly outside the core nations" (Ciccantell and Bunker 2004:571). In the South Korean economy, the steel and shipbuilding industries are mainstay industries ('Rice for Industry') from which many other manufacturing sectors of the export-oriented national economy have benefited. In this paper, we examine the economic ascent of Korea in terms of the new historical materialism (Ciccantell and Bunker 2004) and the rise of Asia (Arrighi 1996; Frank 1998; Arrighi et al. 2003).

South Korean firms, with help from the South Korean state, utilized the globalized raw materials supply networks and organizational and financial strategies created by Japanese firms and the Japanese state since the 1940s to support Japanese economic ascent (Ciccantell and Bunker 2004; Bunker and Ciccantell 2005, 2007). These raw materials supplies critically supported export-oriented manufacturing industries by providing the necessary inputs for low cost, high quality production by the steel and shipbuilding industries. This industrial base undergirded the broader economic competitiveness of the South Korean economy, making possible the remarkable development of the machinery, electronics, construction, and automobile industries within a short period of time. The growth of the Korean steel and shipbuilding industries as generative sectors has been closely linked to the strategies of government and large corporations and the relationships between them, the use of organizational strategies such as international joint ventures, and the adoption of new technologies in the steel and shipbuilding industries.

In order to comprehend the roles of the steel and shipbuilding industries in Korea's rapid economic ascent to a leading role in the global economy, this paper will address three specific questions. First, how did the Korean government foster the development of leading firms (Pohang Iron and Steel Company in the steel industry and Hyundai Heavy Industries in shipbuilding) that became leaders in their global industries? Second, how did the Korean firms survive and prosper in the competition with Japanese firms in these industries? We focus on the main strategies for the success of the Korean steel and shipbuilding industries in terms of organization, international cooperation, and the adoption of various new technologies. Third, what are the implications of the emergence of Chinese competitors and China's rapid economic ascent for the Korean steel and shipbuilding industries and Korea's role in the world economy?

In the next section, we will present a theoretical model of generative sectors and ascent in the global economy, focusing on raw materials acquisition and transport in the steel and shipbuilding industries. Then, we will examine the development strategies of the Korean state in these industries, outline the development of the Korean steel industry and shipbuilding industry, and discuss the growing competition in steel and shipbuilding between Korean, Japanese and 
Chinese firms. The conclusion outlines the implications of East Asian economic ascent and competition for restructuring the global economy.

\section{GENERATIVE SECTORS AND ECONOMIC ASCENT}

The definition of generative sectors in the capitalist world-economy is:

leading economic sectors that are simultaneously key centers of capital accumulation, bases for a series of linked industries, sources of technological and organizational innovations that spread to other sectors, and models for firms and for state-firm relations in other sectors. (Bunker and Ciccantell 1999:107)

The concept of generative sectors is relational and useful as a tool for the comparison of different cases of rising economies across time, which implies that generative sectors in a rapidly ascending economy have significant consequences for changing the world economy (Bunker and Ciccantell 2005:87). Bunker and Ciccantell (2005) argue that globalization has been materially and spatially expanded with 'generative sectors' that drive the rising economies to reach trade dominance and even to challenge the established hegemon by devising new technologies of raw materials extraction of timber, coal, iron, steel, aluminum, and petroleum, forming more competitive patterns of state-sector-firm collaboration, organizing new social and financial institutions, and creating further domestic and international inequalities.

Portugal opened new maritime trade routes to Africa and Asia with the development of the three-masted ship, adoption of Chinese compass, and using iron cannon on ship decks. Portugal expanded trade volumes of American sugar, tobacco, turtle eggs, and spices into the Mediterranean world. The Dutch took the geographical advantages of easy access to materials shipped downriver from the German and Polish interior to develop a sophisticated shipbuilding industry utilizing cranes, wind-driven sawmills, and other labor-saving devices, while the city government of Amsterdam financed ports, docks, locks, dams, and spillways to create economies of scale that lowered the cost of ships. The preeminence of British shipping and shipbuilding was achieved by war with Holland and struggles to control American forests. Britain's shortage of timber for naval shipbuilding resulted in New England's development of important shipbuilding and shipping industries. British innovations in coal, steel, and steamboat technologies supported military dominance and promoted British control over trade in a great variety of commodities, such as tin from Malaya, timber and ore from the Philippines, rubber from the Belgian Congo, cotton from Egypt and India, and copper, nitrates, and oil from Latin America. The U.S. adapted these technologies for agricultural and commercial expansion into Mississippi and the Great Lakes. In combination with Jefferson's charisma and imagination of building the newly formed nation, these technologies facilitated westward expansion into areas of extraordinary ecological diversity and resource abundance (Bunker and Ciccantell 2005).

The rise of Japan was deeply related to the geopolitical context under the aegis of U.S. political/military power. The carefully planned and tailored infrastructure of mines and export transport in the main raw materials suppliers of Australia, Brazil, and Canada gave Japanese firms significant advantages for bargaining over the price of raw materials and establishing other forms of investments, including joint ventures (JV) and long-term contracts (LTC), which resulted in a 
spatially much more dispersed world economy. Domestically, Japan utilized various measures, such as ownership of large ships by shipping firms associated with major industrial groups, to free themselves from dependence on foreign shipping, the construction of MIDAs (Maritime Industrial Development Areas) financed by the state and firms in Japanese ports, and close collaboration between the state and firms, including special subsidies in the form of loans and tax exemptions (Bunker and Ciccantell 2007).

As Japan's ascent showed, successful access to cheap iron ore and coal requires technical solutions to the cost of transport via the construction of larger ships and ports, better railways, and larger warehouses. ${ }^{2}$ It, in turn, will create demand for more and higher quality steel, which in turn makes possible technological innovations to lower the unit cost of steel: "reduced unit costs of steel make shipbuilding cheaper and more competitive and further reduce unit costs of iron and coal transport" (Ciccantell and Bunker 2004:570). The generative sectors of steel and shipbuilding that support domestic economic growth and rapid economic ascent simultaneously create a new system of international political economic relationships and can eventually restructure the capitalist world-economy.

Discussing the relationship between nature and society, Bunker and Ciccantell (2005:83$86,2007)$ provide a series of propositions that we modify somewhat to examine the case of Korean ascent:

1. By introducing technical economies of scale in order to reduce unit costs of raw material and labor, the state and firms use greater volumes of raw materials and greater amounts of capital. This large amount of capital sunk into the built environment requires increasing the financial capacity of the state.

2. Raw materials consumption creates a tension between economies of scale that offer opportunities to reduce costs of processing and transport (potentially creating competitive advantages relative to the existing hegemon and other rising economies) and raw materials depletion and increasing distance to supplies, termed diseconomies of scale. States, industrial sectors, and firms in the generative sectors engage in an often lengthy process of conflict and cooperation, eventually creating a new pattern of state-sector-firm relations that distribute the benefits of growth across sectors and classes. This pattern creates a broad-based political economy supporting growth and provides a model for institutions and state-sector-firm relations in other sectors of the economy that sustain growth over the long term.

3. Technological innovations enhance the ascending economy's commercial power by increasing the size, weight, and speed of ships and by improving the capability of producing higher-valued goods. As transport costs fall and transport infrastructure expands spatially via resolving this contradiction between economies of scale and diseconomies of space, the ascending economy's trade of raw materials and finished products becomes more competitive.

\footnotetext{
${ }^{2}$ Bunker and Ciccantell (1999:114-116) presented a discussion of the roles of railroad and
} highway networks in the ascending economy. 
4. Following Japan's model of dramatic economic ascent via these generative sectors, the steel and shipbuilding industries in South Korea and China contribute to the formation of East Asia as a rapidly growing region within the global hierarchy of inequality. Domestically in South Korea, ascent also contributes to increasing inequalities between the large firms in these industries and their archipelagos of numerous subcontracting companies in terms of wages, working conditions, and state support.

5. In order to sustain economic ascent, dynamic tension between competing and cooperating groups (firms, industry sectors, classes, regions) needs to be managed. The competitive advantages created by organizational and technological innovations and by subsidies from peripheries in these generative sectors lead to global trade dominance. Economic and political competition from the existing hegemon and other ascending economies shapes and constrains long term success, creating both opportunities for growth and competition for firms in rising economies.

This model of generative sectors is specifically applied to historical changes of competitive strategies and international relations that the South Korean economy adopted in the process of ascent. The rising Japanese economy challenged the established U.S. economy in the 1970s and 1980s; since then, the South Korean economy has followed a path very similar to that of Japan. The South Korean economy has been based on the model of coastal heavy industrialization created by Japan, supplying other industries such as automobiles and machinery at lower cost. In the mid-1980s, the South Korean generative sectors began to compete with and eventually overtake Japanese steel and shipbuilding firms. Japanese and Korean rapid industrial ascent to leading positions in the global economy has deepened the processes of raw materials extraction, production, and trade on a global scale, resulting in the restructuring of the worldeconomy, although Japan has not become a hegemon. ${ }^{3}$

\section{THE KOREAN STATE AND DEVELOPMENTAL STRATEGIES FOR THE GENERATIVE SECTORS}

Most analyses stress the 'primacy of the state' and focus on the role of Korean government during the whole process of planning and executing rapid economic growth policies over the past four decades (Amsden 1989; Wade 1990; Cho and Kim 1991; Woo 1991; Sakong 1993; Song 2003; Kohli 2004). As we will discuss below, the role of the state was very important, but the coherence and control of the state should not be overstated. Other groups domestically and internationally also shaped Korea's developmental trajectory, as did the broader evolution of the capitalist worldeconomy and geopolitics in the second half of the twentieth century that created opportunities that were exploited by Korean firms with the support of the Korean state, Japanese firms, the Japanese state, and the U.S. To promote development in the competitive global market, the Korean state

\footnotetext{
${ }^{3}$ Only Japan in Asia has reached core position in the capitalist world-economy (Arrighi et al. 2003). For the analysis of hegemons' rise and fall, especially in a long term historical perspective, see Frank (1998) and Arrighi et al. (2003).
} 
invested financial resources in heavy and chemical industries during the 1970s (Amsden 1989; Woo 1991; Sakong 1993; Song 2003; Kohli 2004), and it continuously played an interventionist role in the whole process of economic growth, not only with short-term growth strategies, but also via a "long-term productivity enhancing project" (Evans 1995). The key role of the South Korean state was to guide the direction and pace of growth by large private firms, the chaebols of Hyundai, Samsung, Daewoo, and others. In return, these conglomerates had to work hard to maintain their financial benefits from the government. Amsden (1989) described South Korean development as 'late industrialization' focusing on the steel and shipbuilding industries: "the government played the part of visionary in the case of Korea's first colossal shipyard, and it was responsible for the Big Push into heavy machinery and chemicals in the late 1970s" (Amsden 1989:81).

The Park Chung Hee regime (1961-1979) initiated the industrialization process of South Korea after the military coup of May 1961. The Park military regime valued and respected the central government bureaucracy created by Japanese colonialism and emphasized the importance of meritocracy, efficiency, education, and discipline in state agencies (Lim 1985; Kohli 2004). In order to aggressively support its economic development program, Park's government nationalized and reorganized the banking sector (Koo and Kim 1992). The Heavy and Chemical Industrialization (HCI) promotion policy required a huge amount of capital that was acquired via foreign loans, especially from the U.S. and Japan.

In order to answer the questions about how the Korean government could overcome the obstacles to the construction of a costly integrated steel mill and large dockyards, why Japanese firms and the Japanese state loaned the capital for these large projects, and how Korean generative sectors could compete with Japanese dominance, we need to understand the international and historical contexts of Japanese, Korean, and, more generally, East Asian economic development not only in terms of acquisition of new technologies, but also in terms of the roles of rising and falling powers, including the U.K., the U.S., Japan, and possibly China (Cumings 1984; Henderson and Appelbaum 1992; Koo and Kim 1992; D'Costa 1994; Ciccantell and Bunker 2002; Arrighi et al. 2003; Kohli 2004; Bunker and Ciccantell 2005). Regarding this context, D'Costa (1994) provided a succinct description of the political background:

In the early years of Park's rule, the U.S. government pressured South Korea to recognize Japan diplomatically. Although considered political suicide at the time, recognition of Japan allowed Park to maintain the public posture of liberalization, diversify global linkages, and ultimately adopt Japan as a model for deepening South Korean industrialization. The U.S., for its part, desired a division of labor that would involve Japan in East Asia...surplus capital accumulated by Japan during the Korean War would ostensibly find an outlet in South Korea. Despite significant opposition, the Japan-Korea Normalization Treaty of 1965 was signed. Park demanded war reparations (Property Claim Funds) from the Japanese as part of the normalization treaty. In this way he not only deflected some of the public outcry but was able to garner about $\$ 500$ million from Japan as war related claims. (D'Costa 1994:56)

U.S. support for South Korea's industrial development as a part of U.S. Cold War strategy in Asia provided capital, technology, market access, and political support that 
undergirded South Korea's rapid domestic transformation, as Cumings (1984), Henderson and Appelbaum (1992) and Kohli (2004) demonstrate. As was the case in the British-American interdependence during U.S. ascent and U.S. support for Japanese reindustrialization after World War II, this type of support from the existing hegemon has been critical for the most dramatic cases of economic ascent (Bunker and Ciccantell 2005, 2007); South Korean economic ascent, and the ascent of China since 1978, have both depended on support from the U.S. and its most important Asian ally, Japan.

For the Pohang steel mill project, the normalization treaty removed the hurdle of financial and technological access. Japan was satisfied with South Korea's recognition and did not view South Korea as an economic threat at that time. In 1969, Japanese Nippon Steel executives and the retired General Park Tae-Jun who led the steel project agreed on technical and financial assistance for the integrated steel mill in Pohang, with around US\$140 million allocated for construction (Sunoo 1989). Thus, the South Korean government could make its own flexible decisions on the size, location, and other aspects of the steel mill. The Korean government's policy to promote HCI in the early 1970s included iron and steel, shipbuilding, nonferrous metals, chemicals, general machinery, electrical equipment, and electronics (Lee 1991). The 'Steel Industry Promotion Law' of 1970 granted POSCO numerous benefits, including low-cost and long term foreign capital, discounts for electricity and rail transport, and limits on the import of steel (Amsden 1989:297). For the plan to construct the second steel mill at Kwangyang in 1981, POSCO secured international loans with low interest rates. Obtaining finance and technology from multiple Japanese and European suppliers allowed the Kwangyang project to start in 1982, and each stage of expansion was completed ahead of schedule. After four stages of expansion, the Kwangyang mill had a capacity 11.4 million tons of steel, making POSCO's total capacity 20.5 million tons (D'Costa 1994:58).

The government provided domestic loans, support for increasing domestic savings, special depreciation allowances, very low tax rates, an enormous expansion of foreign borrowing, and other administrative support (Song 2003). The government made subsidized credit and longterm capital with low interest rates available selectively to exporting companies. ${ }^{4}$ As industrial development proceeded, Park's regime used coercive means and its finance channeling power to oversee the firms in every detail of their planning and operations, rewarding good performers and penalizing poor ones.

Two main factors drove the Korean government to initiate HCI. First, Korea's light manufacturing industries faced rising protectionist barriers in the world market. Therefore, shifting Korea's export strategy toward high value-added products in the world market could help to maintain economic growth. The transition of the Korean economy from light industry to chemical and heavy industry in the 1970s meant that Korea as a latecomer to industrialization had to compete against firms from high wage countries, not against firms from low-wage countries. As a non-economic factor, secondly, the government promoted the defense industry as part of national-security strategy (Sakong 1993:35-36; Rhyu 2001). This national-security strategy resulted from the uncertain geopolitical environment surrounding the Korean peninsula after Nixon's visit to China as an effort to end "the Cold War," which convinced many Koreans of the importance of self-defense (Koo and Kim 1992). Korean government disciplinary interventions

\footnotetext{
${ }^{4}$ Amsden (1989:145-47) presented an excellent analysis of the reciprocal disciplinary subsidy system performed by the Korean state.
} 
such as total control over commercial banking, limiting the number of firms entering a new industry, and controls on prices, capital flight, and commodities shaped aggregate economic concentration and income inequality during the industrialization process (Amsden 1989:15-18). As had been the case during Japan's rapid economic ascent, the pattern of South Korean statesector-firm relations established in the generative sectors brought together the large firms, the state, and a coalition of elites, the middle class, and sectors of the working class in support of this model of development (proposition number two). The intensive policy of subsidy and growth for $\mathrm{HCI}$ led by the Korean state created tight relationships between the state, the generative sectors of steel and shipbuilding, and POSCO and HHI. State funding, protection, and regulation and changing conditions in the world economy provided the opportunities for Korean firms to invest in and profit from heavy industrialization, led by steel and shipbuilding.

\section{THE STEEL INDUSTRY: SHIFTING STRATEGIES FOR COMPETITION}

The Korean military government established Pohang ${ }^{5}$ Iron and Steel Company (POSCO) in 1968, and the company received extensive government support from the beginning, while the small steel mini-mills built during the Japanese colonial period did not receive government support. Because of its huge capital requirements, most Koreans initially opposed the construction of the mill, but POSCO continually expanded its capacity and proved to be successful by the mid1980s. ${ }^{6}$ As a consequence, the Korean steel industry became the catalyst and linchpin for a number of industries, such as automobiles, shipbuilding, containers, railroads, construction, and appliances, which complemented each other in a virtuous cycle of economic growth over the last three decades. The indicators of the contribution by the steel industry as a generative sector are striking. Korean steel production expanded from 2.55 million tons in 1975 to 36.8 million tons in 1995 , to 43.1 million tons in 2000 , and to 48.5 million tons in 2006 , making it the world's fifth largest steel producer (see Table 1). The contribution of the steel industry to the Korean economy is clear from the interdependence between POSCO and the main industries of automobiles, appliances, construction, and shipbuilding (Hogan 2001; Shin and Yoo 2004).

Because of POSCO's tremendous increase of the supply of domestic steel from 20 percent of consumption in the 1970s to more than 90 percent in 2000, the entire Korean economy could sustain continuous growth. Korean automakers, for instance, produced 1.322 million vehicles $(347,000$ were exported) in 1990, and POSCO made 1.426 million tons of steel shipments to the automobile industry in the same year. By 1999, the Korean automobile industry produced 2.832 million vehicles (1.508 million were exported) and POSCO sold 3.542 million

\footnotetext{
${ }^{5}$ In 1967, Pohang, with its deep water shore that could accommodate large bulk carriers, was selected as the location for the plant. In this study the discussion of POSCO focuses on 1967 to 2002, when it was privatized.

${ }^{6}$ Massive investment in heavy and chemical industries in the 1970s was also criticized by many experts, including Korean government officials and economists. For the historical development of the relationships between POSCO and Korean political/military leaders, particularly the relationship between President Park Chung Hee and General Park Tae-Joon who established and led POSCO, see D'Costa (1994) and Chapters 1 and 2 of Hogan (2001:3-36).
} 
tons of steel to the industry (Hogan 2001:42-43). ${ }^{7}$ The Korean appliance industry produces refrigerators, washing machines, microwave ovens, air conditioners, VCRs, and color TVs, and consumed significant amounts of steel to produce 32.9 million units in 1990, rising to 47.5 million units in 1999 (Hogan 2001: 48-51). Projects in the construction industry, including building infrastructure such as highways and bridges, commercial building construction and residential construction, also use huge amounts of steel. In the late 1990s, POSCO's shipments of steel to the construction industry exceeded one million tons per year (Hogan 2001:59-60). Railroads in Korea have recently focused on a high-speed railroad project to connect the cities of Seoul and Pusan, a distance of 412 kilometers, with completion planned for 2010 at a cost of US\$16.3 billion. A more ambitious set of future projects focus on building railroad linkages between Korea, Japan, and China, routing across the Korea-China border and to the Siberian railroad, eventually reaching Europe (Kim, Hong and Nam 2001). It is expected that these projects will generate a high demand for steel, including for rails and structural steel for the construction of railroad stations and facilities. POSCO plans to increase its production of ship steel from its current 3.6 million tons to 4.7 million tons by 2010, due to the boom of the shipbuilding industry in recent years. This will relieve the shortage of high quality ship steel for ships, offshore oil platforms, and plants (Asia Pulse News 2006).

Table 1: Steel Production by Nation, Measured in Million Tons

$\begin{array}{lclllclr}\text { Nation } & \mathbf{1 9 8 0} & \text { Nation } & \mathbf{1 9 9 0} & \text { Nation } & \mathbf{1 9 9 5} & \text { Nation } & \mathbf{2 0 0 6} \\ \text { USSR } & 147.9 & \text { USSR } & 153.9 & \text { Japan } & 101.6 & \text { China } & 423.2 \\ \text { Japan } & 111.4 & \text { Japan } & 110.3 & \text { China } & 95.4 & \text { Japan } & 116.2 \\ \text { U.S. } & 100.8 & \text { U.S. } & 88.6 & \text { U.S. } & 95.2 & \text { U.S. } & 98.5 \\ \text { Germany } & 43.8 & \text { China } & 67.2 & \text { Russia } & 51.6 & \text { Russia } & 70.7 \\ \text { China } & 37.1 & \text { Germany } & 38.4 & \text { Germany } & 42.1 & \text { Korea } & 48.5 \\ \text { France } & 23.1 & \text { Italy } & 25.4 & \text { Korea } & 36.8 & \text { Germany } & 47.2 \\ \text { Canada } & 15.8 & \text { Korea } & 23.1 & \text { Italy } & 27.7 & \text { India } & 43.2 \\ \text { Brazil } & 15.3 & \text { Brazil } & 20.5 & \text { Brazil } & 25.1 & \text { Ukraine } & 40.8 \\ \text { Spain } & 12.6 & \text { France } & 19.0 & \text { Ukraine } & 22.3 & \text { Brazil } & 30.9 \\ \text { India } & 9.4 & \text { U.K } & 17.9 & \text { India } & 22.0 & \text { Italy } & 31.5\end{array}$

Source: Steel Statistical Yearbook (IISL) and Yearbook of Iron and Steel (Korean Iron and Steel Association - www.kosa.or.kr/statistics)

POSCO, with the total support of the Korean state, developed five key strategies over the last four decades in order to reduce steel production costs and support the broader process of

\footnotetext{
${ }^{7}$ Hogan (2001) expected a continuous growth of demand for corrosion resistant galvanized steel over the next 20 years and the mills of POSCO and Kwangyang can deliver high quality coldrolled sheets. By building the second plant at Kwangyang in 1985, POSCO could respond promptly to the market's diverse needs: "a system of one company two works, which enables us to pursue less quantity but greater product variety " (Hogan 2001:39). For a detailed discussion about the benefits of building Kwangyang mills in terms of size and new technology, see D'Costa (1994:60-63).
} 
Korean economic growth (Park 2003). First, POSCO adopted new technologies and facilities from many other areas, including Japan and Europe (Enos and Park 1988), e.g., automation technology, larger scale blast furnaces, continuous casting equipment, minimill technology, and a variety of other innovations (Hogan 2001). D'Costa (1994:49-50) outlined the reasons for adopting imported technology. First, the enhancement of export potential required a superior quality of steel to meet international standards. Second, because the scale of production is inversely correlated with unit cost, importing larger scale technology reduces costs. Third, modern technology combined with disciplined and low wage labor create a structural competitiveness. Fourth, the transfer of technology from Japan became possible because Japanese firms and the Japanese state did not view South Korea as a threat during the 1970s. Furthermore, two Japanese steel producers, Nippon Steel and Mitsubishi Heavy Industries, faced with global overcapacity and a political climate encouraging transferring heavily polluting industries out of Japan, thought that South Korea was an attractive alternative (D'Costa 1994:59). Changes in the global economy, driven in large part by Japan's rapid economic ascent, created important opportunities that POSCO, with tremendous help from the Korean state, seized to become one of the world's largest steel firms and a critical component of the global economy.

Second, POSCO committed significant capital and human resources to technological innovations and research and development by establishing two of the world's leading research organizations, Pohang University of Science and Technology (POSTECH) in 1986 and the Research Institute of Industrial Science and Technology (RIST) in 1987. While POSTECH conducts basic scientific research, RIST pursues the development of applied technologies from which POSCO benefits via pilot plants and later commercial production. POSCO's technological advances include the FINEX plant ${ }^{8}$ (Steel News 2003) and Smelting Reduction and Near-NetStrip Casting (Strip Casting). This research and development innovation strategy will be a key element in Korea's effort to maintain and further enhance its position in the world economy in the face of China's rapid economic growth.

Third, POSCO's personnel policies helped it achieve and maintain its high level of global competitiveness. POSCO is an exemplar of the 'rise of the segmented labor market,' which utilizes a hierarchical multi-tier wage structure of managers, regular workers, and contracted out workers. ${ }^{9}$ It is similar to the Japanese divided structure of "permanent and transitory employees." Regular workers in POSCO are highly paid. On the other hand, there are "contracted-out (temporary)" blue collar workers who take the menial tasks of "relining, cleaning, packing, preparing ingot molds, scarfing, and treating slabs" (Park 1991). In the 1980s, they made up around $24 \%$ of total employees at POSCO. It is estimated that POSCO saved around $15 \%$ of total labor costs by hiring temporary workers (Amsden 1989). POSCO has a military-style operation to foster strong motivation among workers, an extensive training program that facilitates very low rates of turnover and absenteeism (e.g., only $0.07 \%$ of labor days in 1984 were lost to absenteeism) (Amsden 1989:212), a very weak labor union (POSCO Fact Book 2001, 2006) and large numbers of irregular workers at its Oejoo Opchae (subcontracted companies).

\footnotetext{
${ }^{8}$ The FINEX plant uses powder iron, smaller than $8 \mathrm{~mm}$. Over $80 \%$ of world iron production is in the form of powder, of which the earth has plenty of reserves.

${ }^{9}$ POSCO has 425 job categories of which the largest number of workers are involved in the job of data collection, with only a small number of master steel makers (or saint technician). Most tasks are performed using computerized programs.
} 
Fourth, POSCO, built deepwater ports in Young Il Bay and Kwangyang Bay, replicating the Japanese strategy of using ocean-going large bulk carriers coupled with international investments and bargaining skills to secure long-term access to iron ore via long-term contracts rather than the foreign direct investment model of the steel firms in the U.S. and Europe. This Japanese strategy ${ }^{10}$ had completely changed the conditions in global raw materials industries, and POSCO made excellent use of this Japanese-created opportunity. The growth of steel production by POSCO required a steady increase of imported raw materials. POSCO's imports of iron ore grew from 11.6 million tons in 1981 to 27.7 million in 1991, to 39.5 million in 2001, and to 42.2 million tons in 2005 (POSCO Fact Book 2000-2006), an annual growth rate of over 6 percent. POSCO imported 20.8 million tons from geographically close Australia, 57 percent of the total, 10.5 million tons from Brazil, 29 percent of the total, and 2.6 million tons from India, 7 percent of the total, in 2000. The major sources for coal are Australia, Canada, the United States, and China.

Fifth, in order to expand this raw materials strategy for securing stable sources of supply, POSCO made joint venture investments in other countries. Two international joint ventures in coal were formed: Miller Pohang Company (with the Mount Thorley Coal Mine Project in Australia) in 1981 and POSCAN (Greenhills Coal Mine Project in Canada) in 1993. KOBRASCO, a Brazilian joint venture to produce iron ore pellets, was formed in 1996 (see Table 6.4 in Hogan 2001:88). The announcement of a new foreign investment plan by POSCO to build an integrated 12 million ton steel plant in Orissa, India in 2006 is an example of its efforts, based on these strategies to secure raw materials. It would be POSCO's first foreign investment in building an integrated steel plant. Orissa has 5 billion tons of iron ore reserves, of which POSCO can utilize mining rights to 600 million tons, adequate for supplies for the next 30 years (Ohmynews 2006).

Each of these strategies was explicitly modeled on Japan's remarkably successful development strategy and, in many ways, was supported by Japanese firms and the Japanese state via financing, joint ventures, and technology sales. The Japan-driven restructuring of the world economy created strategic opportunities that POSCO and the Korean state utilized to promote economic growth. As we will see in the shipbuilding industry, Japan, South Korea, and more recently China are engaged in economic and political relationships of cooperation and competition. Japanese firms and the Japanese state provide capital for, sell technology and products to, and form joint ventures with South Korean and Chinese firms, while simultaneously competing in global markets with these very same firms. This complex interdependence mirrors earlier relationships between the U.S. and Japan (Bunker and Ciccantell 2007) and between the U.S. and Great Britain (Bunker and Ciccantell 2005) and highlights the need for world-systems analysis to examine the rise of East Asia and the potential for restructuring the capitalist worldeconomy as a multidimensional and often contradictory process.

\section{THE SHIPBUILDING INDUSTRY}

The Korean shipbuilding industry contributed greatly to Korean economic growth. The amount of exported ships and marine facilities increased steadily, and ships are one of the three most

${ }^{10}$ For the strategies adopted by the Japanese steel firms, see Bunker and Ciccantell (1999:116119) and Ciccantell and Bunker (2004). 
important export items, along with semi-conductors and automobiles. As a generative sector, the shipbuilding industry produces all different types of ships and ocean facilities for seaborne transport carriers, such as oil tankers, bulk carriers, cargo carriers, gas carriers (LNG), container ships, pure car carriers, fish carriers or trawler ships, naval ships for military defense, and diverse facilities for the development of marine resources, particularly for the offshore oil and gas industry. The production of ships and marine facilities tends to be large scale and largely nonstandardized, so the shipbuilding production process is labor-intensive as well as technologyintensive and very expensive. The world shipbuilding industry tends to have new orders for and construction of ships concentrated in short periods of high demand and high freight rates. Therefore, the shipbuilding industry fluctuates wildly, following the rise and decline of the shipping industry in the world market.

Over the last three decades, the Korean shipbuilding industry dramatically transformed its capability from the production of small coastal ships to the construction of large oceangoing vessels, including large bulk carriers and oil tankers. When Hyundai Heavy Industry (HHI), the largest Korean shipbuilding company, began building ships for export in the 1970s, the international market suffered from excess production capacity and cutthroat price competition. ${ }^{11}$ Diversification of products, membership in the Hyundai group (one of the biggest Chaebols in Korea), and Korean government support helped HHI survive and grow. Specifically, HHI obtained advanced shipbuilding technologies from European shipbuilders during a downturn in the world shipbuilding production cycle in four ways, obtaining

dockyard designs from a Scottish naval architecture firm, A \& P Appledore; ship designs and operating instructions from a Scottish shipbuilding firm, Scottlithgow; experienced European shipbuilders who worked as employees of HHI for the first three years of operations; and production know-how from the Kawasaki shipbuilding company of Japan. (Amsden 1989:276-77)

HHI also benefited greatly from reducing the time and cost of constructing dockyards by using the workers and facilities of Hyundai Construction company, another part of the Hyundai Group. Steady improvements in productivity and labor skills allowed HHI to achieve competitive pricing over the last three decades, moving from only $6 \%$ of world production in the 1970 s to its dominant position in the global shipbuilding industry today. In 1973, Hyundai Heavy Industry constructed the world's largest dockyards in Ulsan Bay, followed by the completion of large dockyards by Samsung in 1979 and Daewoo in 1981 respectively. After the world oil crises, a prosperous phase in the world shipbuilding industry ensued due to the recovery of the global economy, rapid economic growth in Asia, and the International Maritime Organization's regulations calling for the destruction of ships older than 25 years. Also, the Asian financial crisis in 1997 and 1998 drastically decreased the value of the Korean currency, which made Korean shipbuilders' price competitiveness even greater.

\footnotetext{
${ }^{11}$ Hence, HHI was "to alter its product mix away from very large crude carriers (VLCCs) to smaller high-value ships, as well as to branch out into offshore structures, to diversify into steel structures and industrial plants, and to integrate forward in order to stabilize demand" (Amsden 1989: 270).
} 
The Korean government's series of 'Five-Year Plans for Economic Growth,' particularly the Third and Fourth Five-Year plans (1971-1981), promoted the Korean shipbuilding industry. Government support was provided in exchange for risk taking throughout the period from the birth of HHI to the research and development phase of the company: ${ }^{12}$ the granting of a temporary monopoly over steel structure, a government order that Korea's crude oil imports be carried by Hyundai group's newly created merchant marine, and extensive government subsidies for infrastructure and acquiring oversea credit for HHI (Amsden, 1989:274-76). The result is that Korean shipbuilders led the world by completing 21.959 million gross tons $(37.7 \%$ of the world market, compared with Japan's 24.5\%) in 2005 (see Table 2). In 2005, the total value of ship exports was US\$26.4 billion, contributing $48 \%$ of Korea's trade surplus.

Table 2: Shipbuilding (Completion) Statistics by Year, Measured in Million Gross Tons

\begin{tabular}{ccccccccccc} 
& \multicolumn{2}{c}{ Korea } & \multicolumn{2}{c}{ Japan } & \multicolumn{2}{c}{ CESA $^{13}$} & \multicolumn{2}{c}{ China } & \multicolumn{2}{c}{ Others } \\
Year & GT & $\%$ & GT & $\%$ & GT & $\%$ & GT & $\%$ & GT & $\%$ \\
$\mathbf{1 9 8 2}$ & 1,075 & 9.6 & 5,570 & 49.8 & 2,096 & 18.7 & 108 & 1.0 & 2,338 & 20.9 \\
$\mathbf{1 9 8 6}$ & 3,056 & 24.1 & 5,518 & 43.6 & 1,667 & 13.2 & 356 & 2.8 & 2,067 & 16.3 \\
$\mathbf{1 9 9 2}$ & 2,213 & 17.3 & 5,208 & 40.7 & 2,361 & 18.4 & 994 & 7.8 & 2,023 & 15.8 \\
$\mathbf{1 9 9 6}$ & 6,737 & 28.8 & 9,159 & 39.1 & 3,692 & 15.8 & 1,665 & 7.1 & 2,156 & 9.2 \\
$\mathbf{2 0 0 2}$ & 9,719 & 33.6 & 12,363 & 42.8 & 1,411 & 4.9 & 3,070 & 10.6 & 2,335 & 8.1 \\
$\mathbf{2 0 0 5}$ & 21,959 & 37.7 & 14,227 & 24.5 & 6,616 & 11.4 & 9,641 & 16.6 & 5,740 & 9.9
\end{tabular}

Source: Lloyd's World Shipbuilding Statistics; cited from Korea Shipbuilders Association (www.koshipa.or.kr/eng/koshipa3/statistics)

The high performance of Korean shipbuilders results from three main causes. First, tougher environmental regulation by the International Maritime Organization forces firms to switch to operating double-hull tankers by 2010. Secondly, China's fast growing economy increased seaborne trade between Asia and the U.S., so that global shipping companies began to demand the creation of large vessels with the capacity of stacking up to 10,000 containers on the decks (Business Week 2003). Third, economic growth in developing countries such as China and India created high demand for oil and greater use of liquid natural gas (LNG), which in turn stimulated the global search for oil reserves that increased the need for new offshore oil production facilities (Moon 2006).

Notably, the Japanese government prohibited the transfer of advanced technology to South Korea, allowing only the transfer of less advanced technologies (Katzenstein 2003). As a result, the Korean shipbuilding and steel industries increased their investments for the development of new technologies. While Japanese shipbuilders have enjoyed superiority in welding technology for decades, Korean shipyards developed techniques to utilize enlarged metal blocks for welding that use 10 metal blocks of 2,000 tons instead of 100 blocks of 200 tons,

${ }^{12}$ There have been international debates on the fairness of the Korean government's subsidies for the shipbuilding industry. For the details of ongoing debates, see Park and Roh (2002) and EichBorn and Hassink (2005).

${ }^{13}$ CESA includes Poland since 1996, Romania since 2001 and Croatia since 2002 
which contributed to reducing production time. Korean shipbuilders also began to demonstrate their efficiency in the operation of dockyards by constructing ships inland and lifting the constructed ship body onto the sea by using Goliath cranes, barges, and air pressure-driven skids (Ramstad 2007:A8). The number of personnel for research and development in the Korean shipbuilding industry increased from 1,311 in 1996 to 2,360 in 2004, including 165 researchers with Ph.D. degrees (Korea Shipbuilders Association 2006).

In the Korean shipbuilding industry, the number of workers has been increasing, which reflects the high performance of the industry. The number of workers in the industry in 1995 was 77,330 , and it increased to 97,323 by 2004 . However, the increase is concentrated in hadogeup companies (or Oejoo Opchae - subcontracted companies). In the same industry, there was a sharp decrease in technological and skilled jobs from $14.7 \%$ and $64.2 \%$ in 1994 into $11.9 \%$ and $37.3 \%$ respectively in 2004; in contrast, skilled and unskilled jobs in hadogeup companies increased from $13.6 \%$ and $21.2 \%$ to $43.2 \%$ and $115.8 \%$ (see Tables 2 and 3 in Kim 2006). Korean shipbuilders enlarged the labor force of unskilled workers of subcontracting companies in order to reduce labor costs (Woo 2004). Furthermore, Korean shipbuilders worry about the possibility of a shortage of young technicians, an aging labor force, and the general trend among young people to avoid working in the local areas where most dockyards are located. Currently, the proportion of the irregular and hadogeup labor force is over 50\% (Hankyoreh Shinmun 2006). These facts seem to confirm the fourth proposition of increasing domestic inequality within rising generative sectors.

The Korean shipbuilding firms, led first by HHI, and the Korean state were able to utilize the pattern of state-sector-firm relations established in the steel industry to create another generative sector as part of a virtuous cycle of economic development. Shipbuilding uses large amounts of steel and provides low cost, high quality ships to transport large volumes of raw materials imports to Korea and exports of steel, automobiles, and other products to foreign markets. Korean shipbuilding firms and the Korean state took advantage of opportunities in the global economy created by Japan's and, more recently, China's rapid economic ascents to build a globally competitive industry. Korean firms utilized the same strategies of importing foreign technology and expertise, developing their own technologies, and control over a two-tier labor force that had been used in the steel industry.

\section{KOREAN STEEL AND SHIPBUILDING IN THE EAST ASIAN ECONOMY}

South Korean steel production totaled 47.711 million tons in 2005 , ranking fifth with $4.7 \%$ of world steel production, following China, Japan, the United States and Russia. The Korean shipbuilding industry has been challenging Japanese leadership in the global market for a decade, and in 2005 Korean shipbuilders took the lead in world orders of high value-added ships such as very large container ships, LNG tankers, and marine facilities.

The Korean generative sectors of steel and shipbuilding followed the Japanese model, termed the 'flying geese model' ${ }^{14}$ or 'snowball effect' in the rise of East Asia (Arrighi et al. 2003:

${ }^{14}$ The 'flying geese' model assumes that Japanese investment transferred sunset industries to South Korea and Taiwan to facilitate export-oriented industrialization and produce a dynamic division of labor in East Asia. So, Japanese supports were thought of as the most influential factor 
302). However, recognizing the differences between the Korean steel and shipbuilding industries and those of Japan in terms of these strategies provides important insights into how Korean industries and the Korean state fostered ascent in the world economy. In comparing competitiveness in the steel industry between POSCO and Nippon Steel, for instance, Nippon Steel's superiority to POSCO in labor and capital productivity rapidly disappeared in the 1980s and POSCO secured its relative dominance by 1992 (Heo 2002).

In the midst of dramatic developments in the generative sectors, the Northeast Asian nations emerged as a rising force in the world economy. Steel production by the three Northeast Asian nations grew from 23 percent of world production in 1985 to 51 percent in 2005, due to the remarkable growth of South Korea and China (see Table 3). The relationships among the three nations are dynamic and hierarchical, with a number of specialized steel trade items moving between the three nations. Steel exports within the region grew from 14 million tons in 1997 to 21 million tons in 2002, of which Japanese steel exports contributed 72\%. China's import of steel products within the region grew rapidly, but Japan has maintained its superior position in high technology steel production, while South Korea has its relative competitiveness in steel manufacturing processes. China is catching up to the two nations with fast improvements in technological innovations and the introduction of new infrastructure. In steel trade items, Japan provides specialized exports to China of high value-added products such as cold-rolled steel sheet, stainless steel, and plating steel (POSRI 2002). Over 70\% of Japanese steel exports to China are these high value added products, while Chinese exports to Japan are mainly hot coil sheet. The China-Japan steel trade deepens the hierarchical division of labor. In the Korea-Japan steel trade relationship, a relatively horizontal relationship has been transformed into Japanese export specialization to Korea, mainly in crude steel products and a small number of specialized steels. The China-Korea steel trade relationship shows a specialization in cold-rolled sheets and plating steel by Korea since 2001 (see Tables 4-5, 4-6, and 4-7 in Shin and Yoo 2004). It appears that the three nations of China, Korea, and Japan in competition and cooperation have formed a specialized and interdependent division of labor in the steel industry with differences in technology, skilled labor, and production of value-added steel products (POSRI 2003).

Table 3: Combined Share of World Steel Production of Japan, Korea, and China

$\begin{array}{lccccccc} & \mathbf{1 9 5 5} & \mathbf{1 9 6 0} & \mathbf{1 9 7 0} & \mathbf{1 9 8 0} & \mathbf{1 9 9 0} & \mathbf{2 0 0 0} & \mathbf{2 0 0 5} \\ \text { Production Share } & 4.5 \% & 9.7 \% & 18.7 \% & 34.1 \% & 25.9 \% & 32.7 \% & 51.7 \%\end{array}$

Source: IISI and adjusted Table from Shin and Yoo (2004)

In the shipbuilding industry, HHI started its shipbuilding construction in the 1970s without any previous experience, whereas Japanese counterparts' shipbuilding predated World War II (Amsden 1989), eventually displacing previously dominant European and American shipbuilders in the 1960s. Japanese shipping companies tended to buy Japanese-made ships,

for Korea's development, which downplays the importance of state policy. For a succinct explanation and evaluation of the models of flying geese, dependent development, and late comers' learning, see Hill and Kuniko (1996). 
while Korean shipping companies were buying Japanese-built used vessels with favorable conditions of finance and delivery at the time. Although there were underlying circumstantial differences, including world production cycle and geopolitical dynamics for the growth of the industry between Korea and Japan, it was technological and organizational innovation that allowed the Korean industry to survive in the harsh competition. Productivity in shipbuilding is largely determined by equipment automation, operators' skills, ship design quality, and throughput time of production from raw material arrival to the delivery of final product (Amsden 1989).

Japan dominated the shipbuilding industry for more than three decades, beginning in the 1960s (Chida and Davies 1990). Facing severe challenges from South Korea and China, Japan has tried to maintain its technological superiority by focusing on various research and development projects such as new structures of ships, safety technology for ships, pollution free ships, large scale marine facilities, and a computer system for shipbuilding called CMIS. Also, there have been efforts to create an integrated system for production and operation through design rationalization, standardization of parts, and information sharing by different organizations. The Japanese shipbuilders began to lose their global dominance for several reasons. First, Japanese shipyards face difficulties in recruiting new young engineers. In Korea, nearly half of the maritime engineering students from Korean universities surveyed have been hired by the local shipbuilding companies, while only $20 \%$ of new engineering students are hired by the dockyards in Japan. Secondly, this produced a lack of flexibility to adapt to changes in the global market that now demands bigger and bigger vessels, eventually forcing the Japanese to build preformatted ships. In contrast, Korean shipbuilders secured $71.3 \%$ of new orders for LNG carriers, $64.3 \%$ for mega container ships, and $42.4 \%$ for very large tankers in 2005 . Third, over $60 \%$ of Japanese ship production has been for the domestic market, while Korea has a smaller domestic demand (Song 2003), which meant that there was less incentive for Japanese shipbuilders to make technological and organizational innovations.

China is rapidly becoming a leader in the world shipbuilding market, based largely on its growing role in international trade. Chinese government policy calls for transporting its own cargos and containers with its own ships and building its ships in its own shipyards. The goal is to become the leader in the world shipbuilding industry by 2015, and China continues to expand facilities and investment, including building the world's largest dockyard with a capacity of 12 million GT on Changxian Island, 12 kilometers north of Shanghai on the Yangtze River. This dockyard, when completed in 2015, would be twice as large as the HHI dockyard in Ulsan, Korea. China has been integrating 600 small shipbuilding firms into one large shipbuilder and reorganizing related industries into an industrial complex for shipbuilding. Korean shipbuilders worry about the possibility of joint investments by Japanese shipbuilders with advanced technology and Chinese firms with plenty of cheap labor and strong support from their state.

The three East Asian nations dominate the world shipbuilding industry, just as they do the global steel industry, totaling over $78.8 \%$ of global shipbuilding orders in 2005 (see Table 2). In the same year, Korean shipbuilders received 21,960,000 GT, 37\% of world shipbuilding orders, while Japanese shipbuilders secured 14,230,000 GT, 24.5\% of the world total, and Chinese firms received 9,640,000 GT, $16.6 \%$ of the world total. Firms from all three nations do compete, but also frequently work together via joint investments, joint technology development, and specialization in different sectors of each industry, including a high volume of intra-regional trade in steel products. Thus, it is clear that Japan, South Korea, and more recently China are engaged 
in both cooperative and competitive economic and political relationships. Japanese firms and the Japanese state provide capital for, sell technology and products to, and form joint ventures with South Korean and Chinese firms, while simultaneously competing in global markets with these very same firms. Just as is the case in the steel industry, economic and political tensions exist in this complex interdependence, but these three nations are leading a fundamental restructuring of the world economy toward a potential "East Asian Century" as they have risen to dominate global production and trade in these industries.

Figure 1: Shipbuilding Results by China, Japan, and Korea

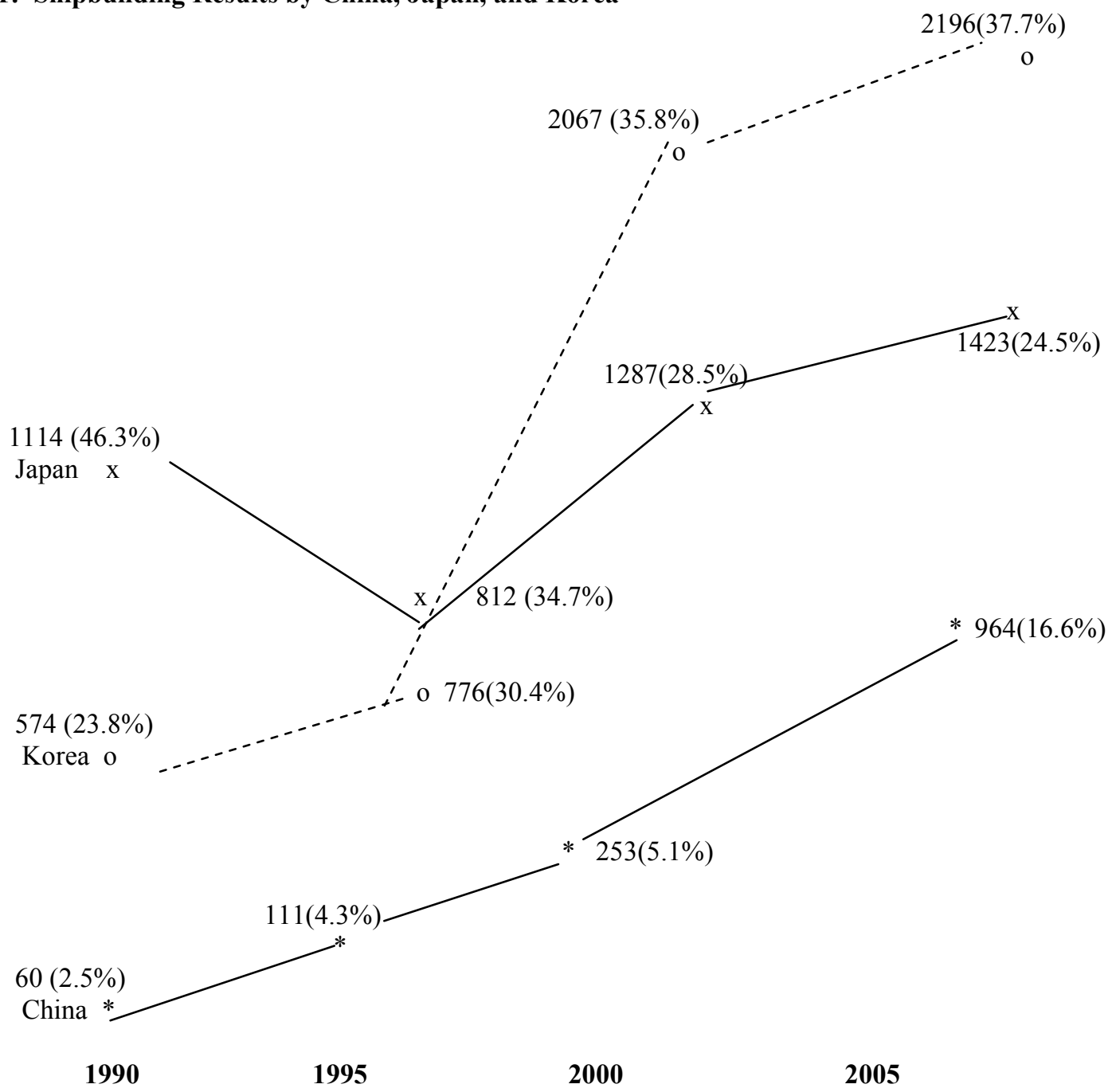

Notes: Measured in 10-Thousand Gross Tons; Number in Parentheses is Share of Global Market

Source: Lloyd's World Shipbuilding Statistics; cited from Korea Shipbuilders Association (www.koshipa.or.kr/eng/koshipa3/statistics) 


\section{CONCLUSION: ASIAN COMPETITION AND RESTRUCTURING THE WORLD ECONOMY}

This study examined the pivotal roles that the generative sectors of the Korean economy, the steel and shipbuilding industries, played in the process of driving economic ascent. The rise of the steel and shipbuilding industries required intensified and expanded use of imported raw materials. Similarly to Japanese strategies in securing raw materials, the Korean generative sectors followed the "golden rule" of economies of scale by producing bigger vessels and constructing larger steel mills equipped with the newest facilities and technologies. Korean steel makers developed long term contracts, diversified their raw materials sources, and made international joint investments. During the whole process of economic growth, the South Korean government's role as market reinforcing 'cohesive capitalist' (Kohli 2004) has been crucial as a guiding director in planning, financing, and evaluation, including the Korean government's export-oriented growth policy with close financial control that focused on the Chaebols, Korean shipbuilders' membership in Chaebol groups, the monopolistic position of POSCO in the Korean economy, and extensive technological and organizational innovations through the adoption of foreign technologies and the development of domestic technologies. As Bunker and Ciccantell (2005) note, the significance of the state's role in the generative sectors is not unique to South Korea. Rather, it is due to the nature of the steel and shipbuilding industries as generative sectors that require massive capital investments and technological innovation, make a high level of contribution to other industries, and require frequent involvement of and subsidies by governments in both developing and developed countries (Shin and Yoo 2004).

To return to our overall research question, can the model of generative sectors explain key aspects of Korean economic ascent better than existing models? As we argued, generative sectors served as crucibles for institutional patterns in South Korea. South Korea's rapid ascent helped reshape East Asia and the capitalist world-economy of the late twentieth and early twentyfirst centuries. Steel and shipbuilding undergirded and shaped South Korea's rise from a low wage, light industry base to a world leader in electronics, automobiles, and other advanced industries. The institutional patterns, relationships with Japan, and Korea's place in the broader rise of Asia were themselves critically shaped by the development of these two industrial sectors. Our analysis integrates seemingly disparate issues into a coherent explanation of Korea's rapid economic ascent. POSCO was state-owned and directed for most of its history, but the shipbuilding industry is privately owned, and these firms often negotiated with the state over development policies, highlighting a complexity not adequately addressed by other models. Further, labor unions and political organizations had important roles in shaping the distribution of gains and the gradual political opening in Korea, factors that are not adequately emphasized in existing models. More generally, these negotiations, accommodations and conflicts reflect the importance of maintaining dynamic tension in sustaining economic ascent (Bunker and Ciccantell 2007) (see proposition number five). This 'dynamic tension' 15 formed and sustained the development policies that were flexible enough to accommodate domestic and global changes in

${ }^{15}$ In some ways, this dynamic tension between material processes of economic ascent, competition in global markets, and contention among social groups parallel the conceptualization of 'hybridity' (Evans 1995) that produces a balance between state control and capacity, interests of market and business elites, and democratic demands and participation. 
industry structure (see Kohli 2004:374-377), the organization and regulation of global trade and investment, transport technologies and costs, and geopolitics, and thereby sustaining Korea's dramatic economic ascent. There has been less dynamic tension in Korea in comparison with Japan, but clearly more than in China up to this point, a critical issue for the future of the East Asia-centered world economy.

There are not only geographically uneven trajectories of growth and decline, but also an accelerating speed of restructuring processes:

with respect to time - restructuring processes have been accelerating so fast that the intervals between the growth to decline stages have become progressively shorter...In the near future, globalization is likely to aggravate this problem as more and more industrial activities are shifted from industrialized to low-cost countries. (Eich-Born and Hassink 2005:635)

It is likely that Japan's leading economic position in Asia is being weakened and may give way to a Chinese era via a short period of transition in which Korean generative sectors play a certain role (Ciccantell and Bunker 2004). A high level of participation in the global economy made the Korean steel and shipbuilding industries more globally competitive in terms of negotiations for raw materials, production technologies, and the production of high value-added items. As a consequence of the rise of Asia, more deeply hierarchical structures of labor forces (regular versus irregular jobs), and inequality between the region of East Asia and the rest of Southeast Asia (Arrighi et al. 2003), between East Asia and its major raw materials supplying countries (Australia, Brazil, and Canada) (Bunker and Ciccantell 2005), and between Chaebols and subcontracted companies that reduced costs emerged.

Domestically, as Amsden (1989:147) remarked, the "state in Korea was able to consolidate its strength with respect to both business and labor." Later, a hierarchical structure between big businesses and the archipelago of subcontracting companies with millions of irregular workers also emerged, which might tarnish the splendid ascent of South Korean economy. ${ }^{16}$ In the international context, on the other hand, historical, political, and economic dynamics are entwined during the ascent processes and the rise of 'East Asia as a world region' (So 1995; Frank 1998; Arrighi et al. 2003), resulting in a new formation of regional and international inequality (Arrighi 1996). By focusing on the generative sectors, it turns out that the simplistic 'flying geese model' (Kojima 1977) is misleading for understanding South Korea's rise to become a challenging player in the world steel and shipbuilding industries. ${ }^{17}$ Understanding the historical causes and developmental paths of East Asian countries demands a comprehension of their historical heritages (Cumings 1984; Woo-Cumings 1999), material and cultural backgrounds,

\footnotetext{
${ }^{16}$ Reportedly, the labor strike at Pohang in Korea in 2006 was due to the inequalities in wages and working conditions between POSCO and its subcontracting company, POSCO Construction (Hangyeorae Shinmun, July 2006. at www.hani.co.kr). Recent changes in the relationship between the Korean state and big businesses from a hierarchical to a symbiotic one (Kim 1997), the privatization of POSCO (Nam 2003), and Hyundai Auto's new integrated steel mill are all important topics, but beyond the scope of this study.

${ }^{17}$ Temporary setbacks such as the Asian financial crisis of 1997 are not preventing sociologists from focusing on the underlying long term trend of the rise of Asia (Arrighi et al. 2003).
} 
and political factors including the role of the state (Koo and Kim 1992; Woo-Cumings 1999; Kohli 2004), especially the role of the U.S. as a hegemon in East Asia ${ }^{18}$ and the benefits that Japan received from the Korean War (1950-1953) (Bunker and Ciccantell 2005; Arrighi et.al. 2003:299-308). Bunker and Ciccantell's (2005) explanation of Japanese rise in raw material acquisition and trade as the anomalies of trade dominance is suggestive:

Under the aegis of U.S. diplomatic, military, and financial support, the Japanese thus culminated historical processes of globalization by globalizing two of the lowest value-to-volume industrial inputs. The increases in the scale and scope of raw materials transport and procurement under the three decades of unequal partnership between Japan and the United States...Their extreme speed - and evident precariousness - may well be due to the fact that their roots were geopolitical rather than spatio-material. (Bunker and Ciccantell 2005:219)

In the near future, a number of political factors, such as North Korea's effort to join the global economy and its relations with neighboring countries, political changes (possibly democratization) in China, and the formation of the Asian Free Trade Agreement (Southeast Asia plus three East Asian countries, China, Japan, and Korea) (Lim 2003) will have important impacts on the restructuring of the capitalist world-economy.

\section{REFERENCES}

Amsden, Alice. 1989. Asia's Next Giant: South Korea and Late Industrialization. New York: Oxford University Press.

. 1994. "Why Isn't the Whole World Experimenting with the East Asian Model to Develop?" World Development 22:627-633.

Appelbaum, Richard and J. Henderson. 1992. States and Development in the Asian Pacific Rim. Newbury Park, CA: Sage Press.

Arrighi, Giovanni. 1996. "The Rise of East Asia: World Systemic and Regional Aspects." International Journal of Sociology and Social Policy 16(8):6-44.

Arrighi, Giovanni, Takeshi Hamashita, and Mark Selden. (eds.) 2003. The Resurgence of East Asia: 500, 150 and 50 Year Perspective. London: Routledge.

Asia Pulse News. 2006. "POSCO to Increase Annual Ship Steel Production by 1.1 Million Tons." 5 July 2006.

Bradshaw, York, Young Kim and Bruce London. 1993. "Transnational Economic Linkage, the State, and Dependent Development in South Korea, 1966-1988: A Time Series Analysis." Social Forces 72:315-345.

\footnotetext{
${ }^{18}$ For the role of the U.S. in East Asian geopolitics in helping Japan to quickly reindustrialize, see Henderson and Appelbaum (1992), So and Chiu (1995), and Bunker and Ciccantell (2005:218220). This study concurs with the argument of Arrighi, Hamashita, and Selden (2003:5) who see East Asia as a world region rather than world-economy: "an autonomous entity encompassing multiplicity of interrelated material cultures and polities."
} 
Bunker, Steven and Ciccantell, Paul. 1999. "Economic Ascent and the Global Environment: World-Systems Theory and the New Historical Materialism." Pp. 107-122 in Ecology and the World-System, edited by W. Goldfrank, D. Goodman and A. Szasz. Westport: Greenwood.

Bunker, Stephen and Paul S. Ciccantell. 2005. Globalization and the Race for Resources. Baltimore: Johns Hopkins University Press.

Bunker, Stephen and Paul S. Ciccantell. 2007. East Asia and the Global Economy: Japan's Ascent, with Implications for China's Future. Baltimore, MD: Johns Hopkins University Press.

Burkett, Paul and Martin Hart-Landsberg. 2000. "Alternative Perspectives on Late Industrialization in East Asia: A Critical Survey." Review of Radical Political Economics. 32:2:222-264.

Business Week. 2003. "Monsters on the High Seas; As China's Exports Swell, Korea and Japan are Launching Gargantuan Container Ships." 13 October 2003.

Ciccantell, Paul and Bunker, Stephen. 2002. "International Inequality in the Age of Globalization: Japanese Economic Ascent and the Restructuring of the Capitalist World-Economy." Journal of World-Systems Research 8(1):62-98.

. 2004. "The Economic Ascent of China and the Potential for Restructuring the Capitalist World-Economy." Journal of World-Systems Research 10(3):565-589.

Chida, Tomohei and Peter Davies. 1990. The Japanese Shipping and Shipping Industries. London: Athlone Press.

Cho, Lee-Jay and Yoon Hyung Kim. 1991. "Major Economic Policies of the Park Administration," Pp.15-40 in Economic Development in the Republic of Korea: A Policy Perspective, edited by Cho, L. and Y. Kim. East-West Center University of Hawaii.

Cumings, Bruce. 1984. "The Origins and Development of the Northeast Asian Political Economy: Industrial Sectors, Product Cycles, and Political Consequences" International Organization 38:1-40.

Cutler, Harvey and Terutomo Ozawa. 2007. "The Dynamics of the 'Mature' Product Cycle and Market Recycling, Flying-Geese Style: An Empirical Examination and Policy Implications." Contemporary Economic Policy 25:67-78.

D'Costa, Anthony. 1994. "State, Steel, and Strength: Structural Competitiveness and Development in South Korea." Journal of Development Studies 31(1):44-81.

Deyo, Frederic, C. 1987. The Political Economy of the New Asian Industrialism. Ithaca: Cornell University Press.

Eich-Born, Mario and Hassink, Robert. 2005. "On the Battle Between Shipbuilding Regions in Germany and South Korea." Environment and Planning 37:636-656.

Enos, John and W.H. Park. 1988. The Adoption and Diffusion of Imported Technology: The Case of Korea. New York: Croom Helm.

Evans, Peter. 1995. Embedded Autonomy: States and Industrial Transformation. Princeton University Press.

Frank, A. Gunder. 1998. ReOrient: Global Economy in the Asian Age. Berkeley, CA: University of California Press.

Gereffi, Gary 1992. "New Realities of Industrial Development in East Asia and Latin America: Global, Regional, and National Trends." Pp.85-112 in States and Development in the Asian Pacific Rim, edited by Richard Appelbaum and Jeffrey Henderson. London: Sage. 
Hankyoreh Shinmun. 2006. http://www.hani.co.kr. 7 August 2006.

Hayter, Roger and David Edgington. 2004. "Flying Geese in Asia: The Impacts of Japanese MNCs as a Source of Industrial Learning." Tijdschrift voor Economische en Sociale Geografie 95(1):3-26.

Henderson, Jeffrey and Richard Appelbaum. 1992. "Situating the State in the East Asian Development Process," Pp.1-26 in States and Development in the Asian Pacific Rim, edited by Richard Appelbaum and Jeffrey Henderson. London: Sage.

Heo, Yoon. 2002. "Comparative productivity of POSCO and Nippon Steel," Journal of Korea Trade Research 27(3):245-264.

Hill, Richard and Fujita, Kuniko. 1996. "Flying Geese, Swarming Sparrows or Preying Hawks? Perspectives on East Asian Industrialization." Competition and Change: The Journal of Global Business and Political Economy 1(3):285-298.

Hogan, William. 2001. POSCO Strategy: A Blueprint for World Steel's Future. Lanham, MA: Lexington Books.

IISL 1980-2006. Steel Statistical Yearbook. http://www.kosa.or.kr/statistics.

Katzenstein, Peter. 2003. "Japan, Technology and Asian Regionalism in Comparative Perspective," Pp. 214-258 in The Resurgence of East Asia: 500, 150, and 50 Year Perspective, edited by Giovanni Arrighi, Takeshi Hamashita, and Mark Selden. London: Routledge.

Kim, Eun Mee. 1997. Big Business, Strong State: Collusion and Conflict in South Korea Development, 1960-1990. Albany: State University of New York.

Kim, Joo Seob. 2006. Development of Human Resources in Shipbuilding Industry. Labor Review, KLI (Korea Labor Institute). Seoul, Korea.

Kim, Won-Bae, Sung W. Hong and K. Nam. 2001. Building Infrastructure for the Facilitation of Economic Cooperation in Northeast Asia in the 21st Century: Focusing on Land Transport Linkages between Korea and China. Korea Research Institute for Human Settlements. Seoul, Korea.

Kohli, Atul. 2004. State-Directed Development. Cambridge: Cambridge University Press.

Kojima, Kiyoshi. 1977. Japan and a New World Economic Order. Boulder, CO: Westview Press. . 2000. "The 'Flying Geese' Model of Asian Economic Development: Origin, Theoretical Extensions, and Regional Policy Implications." Journal of Asian Economics 11:375-401.

Koo, Hagen and Eun Mee Kim 1992. "The Developmental State and the Capital Accumulation of South Korea." Pp.121-149 in States and Development in the Asian Pacific Rim, edited by Richard Appelbaum and Jeffrey Henderson. London: Sage Press.

KOSA (Korea Iron \& Steel Association). 2002 and 2006. Steel Statistical Yearbook. Seoul, Korea. http://www.kosa.or.kr/statistics.

Korea Shipbuilders Association. 2006. Yeongu Inryk hyunhwang (Personnel for R \& D). http://www.koshipa.or.kr.

Korea Shipbuilders Association. 2003. Shinchosun shijang donghyang and Jeonmang (Prospects of New Global Shipbuilding Market). Report 03-10. www.koshipa.or.kr.

Korhonen, Pekka. 1994. "The Theory of the Flying Geese Pattern of Development and its Interpretations." Journal of Peace Research 31(1):93-108.

Lee, Suk-Chae. 1991. "The Heavy and Chemical Industries Promotion Plan (1972-1979)." Pp. 431-471 in Economic Development in the Republic of Korea: A Policy Perspective, edited by Cho, L. and Y. Kim. East-West Center University of Hawaii. 
Lim, Hyun-Chin. 1985. Dependent Development in Korea: 1963-1979. Seoul: Seoul National University Press.

Lim, J.S. 2003. "FTA Formation in East Asia and Its Impact on Steel Industry." POSRI Management Report 3(1):96-119.

Martin, William G. 1990. Semiperipheral States in the World-Economy. New York: Greenwood Press.

Moon, Il. 2006. "Korea Shipbuilding Industry Sails Ahead." Business Week Online. http://www.businessweek.com. 15 May 2006.

Nam, SiKyung. 2003. "MinYoungWha JeongChaeki Seigye Jooyo Cheolgangsaae michin Younghyang (Privatization and its Impacts on Major Steel Companies in the World)" POSRI (POSCO Research Institute) Management Report. 3(2):5-29.

National Statistical Office. 2004. Statistical View of Korea in the World. Daejeon, Korea. http://www.nso.go.kr.

Ohmynews. 2003. Ohmynews.com Seoul, Korea. 6 June 2003. http://ohmynews.com.

Ozawa, Terutomo. 2001. "The 'Hidden' Side of the 'Flying-geese' Catch-up Model: Japan's Dirigiste Institutional Setup and a Deepening Financial Morass." Journal of Asian Economics 12:471-491.

. 2003. "Pax Americana-led Macro-clustering and Flying-Geese-Style Catch-up in East Asia: Mechanisms of Regionalized Endogenous Growth." Journal of Asian Economics 13:699713.

. 2005. Institutions, Industrial Upgrading and Economic Performance in Japan: The FlyingGeese Paradigm of Catch-up Growth. Northampton, MA: Edward Elgar.

Park, Kwang-Seo and Seung-hyuk Roh. 2002 "A Study on the Background and Negotiations around a Trade Dispute Regarding the Shipbuilding Industry of Korea and the EU." Journal of Korea Trade Research 27(2):405-426.

Park, Hyeon Seong. 2003. "Determinants of Leadership in the World Steel Industry and Korean Steel Industry." POSRI Management Report. 3(1):36-59.

Park, Joon-sik. 1991. "A Study on the Changes of Production Technology and Labor Processes in the Steel Corporation in Korea." Korean Journal of Sociology 25:53-70.

Peng, Dajin. 2002. "Invisible Linkages: A Regional Perspective of East Asian Political Economy." International Studies Quarterly 46(3):423-447.

POSCO Fact Book. 2000-2006. POSCO Research Institute of Seoul, Korea.

http://www.posco.co.kr/homepage/docs/en/ir/data/dn/factbook_en/pdf.

POSRI. 2002. "Domestic and International Major Issues in Steel Industry" Jan. Steel Focus. Seoul, Korea.

POSRI. 2003. "Korea, China, and Japan's Trade Structure of Steel and Cooperation." Business Forum. Seoul, Korea.

Ramstad, Evan. 2007. "Korean Shipbuilders take Novel Construction Tack." Wall Street Journal. 12 June 2007 Section A8.

Rhyu, Sang Young. 2001. “The Political Economy of POSCO's Growth: Government-Business Relations, Continuity Debate, and Rent-Seeking Behavior." Korean Journal of Political Science 35(2):67-87.

Romm, Joseph. 1992. “Japan's Flying Geese.” Forbes. 150(12):108-112.

Sakong, Il 1993. "Korea in the World Economy." Institute for International Economics. Washington,DC. 
Shin, HyunGon and SeungNok Yoo. 2004. "Dongbuka Sanop Hyupryukui Ganeungseong: Cholgangsanopeul joongshimeuro (Possibility of Industrial Cooperation in Northeast Asia over Steel Industry)." POSRI Research Report. Seoul, Korea.

So, Alvin and Stephen Chiu. 1995. East Asia and the World Economy. Thousand Oaks, CA: Sage Song, Byung-Nak 2003. (3rd ed.) The rise of the Korean economy. Oxford University Press.

Steel News. 2003. "POSCO completes construction of FINEX DEMO plant." June 3rd.

Sunoo, Harold. 1989. South Korean Economy: Success or Failure: An Analysis of Export Oriented Economic Policy. Virginia Beach: Heritage Research House.

Wade, Robert. 1990a. "Industrial Policy in East Asia: Does it Lead or Follow the Market?" Pp.231-266 in Manufacturing Miracles, edited by G. Gereffi and D. L. Wyman. Princeton: Princeton University Press.

. 1990b. Governing the Market. Princeton: Princeton University Press.

. 1996. "Japan, the World Bank, and the Art of Paradigm Maintenance." New Left Review 217:3-36.

Woo, Jung-en. 1991. Race to the Swift: State and Finance in Korean Industrialization. New York: Columbia University Press

Woo, Yeon Seob 2004. "A Study on the Spatial Features of Shipbuilding Subcontract Structures." Korean Journal of Geography 39(1):116-131.

Woo-Cumings, Meredith. 1999. The Developmental State. Ithaca: Cornell University Press.

World Bank. 1993. The East Asian Miracle. New York: Oxford University Press. 